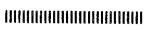

論文

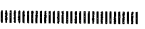

\title{
散漫相転移を示す強誘電体単結晶における動的分域観察
}

\author{
加藤浩一郎・鈴木加代子 ・ 内 野 研二 \\ (上智大学理工学部物理学科, 102 東京都干代田区紀尾井町 7-1)
}

\section{Observation of the Domain Motion in Ferroelectric Single Crystals with a Diffuse Phase Transition}

\author{
Koichiro KATO, Kayoko SUZUKI and Kenji UCHINO \\ (Department of Physics, Sophia University, 7-1, Kioi-cho, Chiyoda-ku, Tokyo
}

102)

\begin{abstract}
Optical or electron microscopes have been usualy used to observe ferroelectric domains. But they have some difficulties in applying an external electric field or in changing the temperature of a sample. A CCD microscope has been developed for the domain observation by combining a low magnification object-lens and a high resolution CCD sensor. The CCD microscope revealed more than $\times 1000$ magnification on a CRT display with a very bright view. Moreover, it is easy to apply an electric field on the sample because of a sufficient distance between the object-lens and the sample. The image of the domain motion is instantaneously recorded with a VTR. Single crystals of the $(1-x) \mathrm{Pb}\left(\mathrm{Zn}_{1 / 3} \mathrm{Nb}_{2 / 3}\right) \mathrm{O}_{3}-x P b T i \mathrm{O}_{3}$ system prepared by the flux method were used. This solid solution system exhibits a morphotropic phase boundary between rhombohedral and tetragonal phase near $x=0.1$. The phase transition behavior from ferroelectric to paraelectric phase becomes sharp with increasing $\mathrm{PbTiO}_{3}$ concentration ( $x$ ) in comparison with a diffused phase transition in $\mathrm{Pb}\left(\mathrm{Zn}_{n_{1 / 3}} \mathrm{Nb}_{2 / 3}\right) \mathrm{O}_{3}$. Our observation demonstrated that the ferroelectric domain motion is closely correlated with the phase transition diffuseness and dielectric relaxation.

[Received March 6, 1990; Accepted April 13, 1990]
\end{abstract}

Key-words : Domain, Diffuse phase transition, Relaxor ferroelectric single crystal, CCD microscope

\section{1. 緒 言}

従来, 強誘電体の分域の直接観察には, 光学顕微鏡あ るいは電子顕微鏡が使用されてきた。しかしながら，通 常の光学顕微鏡では, 倍率が 1000 倍程度が限界と言わ れ, その倍率では像が暗く, また収差除去用液体のため に, サンプルの温度を変化させたり, 電界をかけること はできない. また, 電子顕微鏡も, 操作の繁雑さに加え て，電界等を印加することは困難である。

このような問題点を解決し, 強誘電体の分域のダイナ ミカルな挙動をとらえるために, 本研究では, 低倍率の 対物レンズ $(\times 20)$ と高性能 CCD を組み合わせること により, モニター上の倍率が約 1300 倍で, 非常に視野 の明るい顕微鏡を構成した。

この顕微鏡を用いることにより，強誘電体等の結晶を 薄く $(100 \mu \mathrm{m}$ 程度 $)$ し，更に光学研磨することにより， 容易にその分域構造を観察することができる。更に，开 ンプルに電極を取り付けることにより, 電界の印加も容 易であり，また，サンプルと対物レンズ間の距離が十分 とれるので, 昇温用サンプルホルダーを取り付けること も可能である. 更に，CCDをVTRに接続することに より，観察結果をそのままビデオに録画することができ
る。

本研究では, これらの装置を使用して, 最近高誘電率 コンデンサー材料として特に注目されている，複合ペロ ブスカイト酸化物の一つである亜鉛二オブ酸鉛とチタン 酸鉛の固溶系単結晶について, 温度を変化したときと, 電界を印加したときの，それぞれの分域の変化の様子を 克明に観察し，ビデオに収めることができた。本論文で はこの観察結果を写真にして, その動的な分域の観察結 果について報告する。

\section{2. 実験}

\subsection{CCD 顕微鏡の構成}

本観察で使用した顕微鏡は，次のようなものである。 まず，電界を印加したときの観察に使用したものは，い わば簡易型のもので, 顕微鏡部の大きさは高さ $30 \mathrm{~cm}$, 横 $15 \mathrm{~cm}$, 奥行き $25 \mathrm{~cm}$ である（図 1). 特長としては, まず詨物レンズに 20 倍と低倍率のものを用いたので, サンプル台上の試料と対物レンズとの間の距離を十分に とれるので, 電界等を比較的容易に試料にかけることが できる、また，昇温用のサンプルホルダーも，十分に取 り付ける余裕がある. サンプル台の前後・左右の位置ぎ 
めには，マイクロメーターを使用しており，1 ミクロン 単位の移動が可能である。そして, この CCD カメラを VTRに接続することにより, 強誘電分域の電界印加時 のダイナミカルな応答を, 随時観察し, また記録・再生 することができる。この顕微鏡の構成では, モニタ一画 面上において約 1300 倍の画面を得たが，本論文ではそ の画面を写真に撮影したものを用いたので, その倍率は 約 1000 倍である.

温度を変化したときの観察には, リンカム社製の顕微 鏡用冷却・加熱装置 $(\mathrm{TH}-600 \mathrm{RH})$ を用いた。この装 置は $-180^{\circ} \mathrm{C}$ から $+600^{\circ} \mathrm{C}$ まで温度を変化させることが でき，その温度精度は土0. $1^{\circ} \mathrm{C} \sim \pm 0.5^{\circ} \mathrm{C}$ とっている. また, VTRやカメラに直接その変化の様子を収如る とができる。この装置は, 図 2 に示すようにコントロー

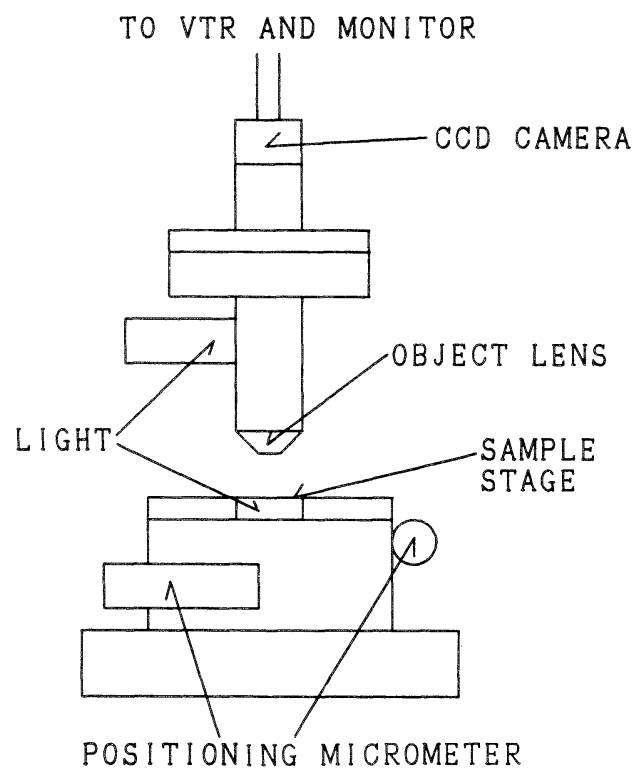

Fig. 1. CCD microscope system. Magnification of the object lens is 20. Final magnification on the monitor is about $\times 1300$.

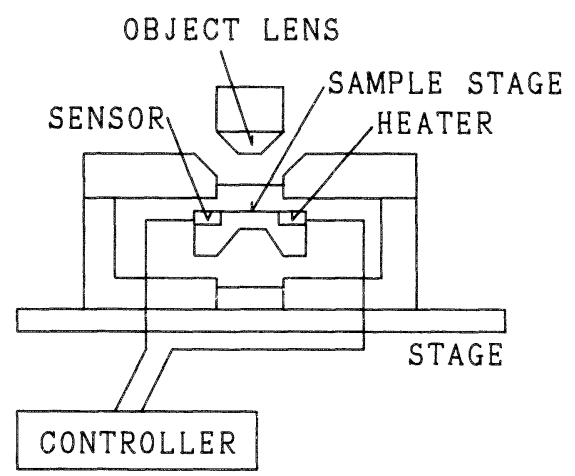

Fig. 2. Sample stage used for heating, controllable up to $600^{\circ} \mathrm{C}$ with the temperature precision $0.1^{\circ}-0.5^{\circ} \mathrm{C}$.
ラ部とステージ部から構成されており，このステージ部 は, 中央部に熱セル（試料台）があり，この熱セルはコ ントローラによってその温度変化を制御できる。この顕 微境を用いることにより，モ二タ一画面上に約 1000 倍 程度（対物レンズ× 20 使用）の画像が得られる。

\section{2 単結晶の作製}

今回の観察に用いた亜鉛二オブ酸鉛とチタン酸鉛の固 溶系単結晶の作製方法としては，フラックス法といわれ る融剂を用いる方法を用いた1)。この融剤には酸化鉛 ( $\mathrm{PbO})$ を用いて，まず白金るつぼに原料粉 $(\mathrm{PbO}$, $\left.\mathrm{ZnCO}_{3}, \mathrm{Nb}_{2} \mathrm{O}_{5}, \mathrm{TiO}_{2}\right)$ と $\mathrm{PbO}$ を $1: 1$ の比に入れ, 密 閉する。これを $1200^{\circ} \mathrm{C}$ で溶解させた後, 毎時 $1^{\circ} \mathrm{C}$ から $5^{\circ} \mathrm{C}$ の冷却速度で $850^{\circ} \mathrm{C}$ までゆっくりと降下させ, 単 結晶を成長させる。得られる単結晶は数センチにおよぶ ものもあり，形は不定形でバルク状である. 図 3 にこの 単結晶作製のフローチャートを示した.

\section{3 観察用試料の作製方法}

更に 2.1 節で述べたような CCD 顕微鏡を用いて観察 するための, 実際の観察用試料の作製方法について述べ る.まず得られた試料を，スライドガラスの中央に瞬間 接着剂を用いて接着する. 次にこのようにして固定した 試料を, 擪めのガラス板上で研磨する. 更に, このよう にして薄くなった試料を，ダイヤモンドペーストを用い て両面とも光学研磨を行う。このようにして, 厚さ 100 $\mu \mathrm{m}$ 以下の極めて薄い観察用の試料ができる。更に，電 界を試料の<111>方向にかけるために, 試料表面に電 極をつける.今回の観祭で用いた試料では，その電極間
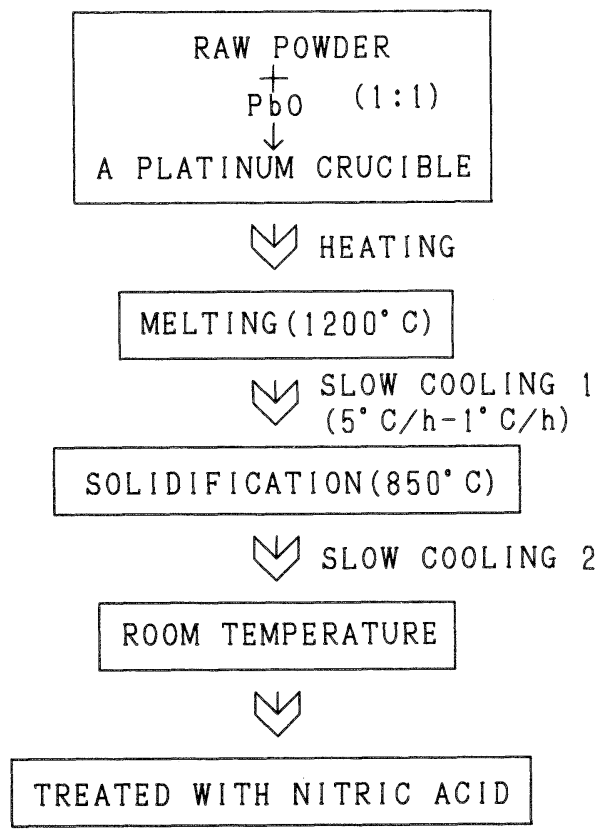

Fig. 3. Preparation flow-chart for single crystals of the $\mathrm{Pb}\left(\mathrm{Zn}_{1 / 3} \mathrm{Nb}_{2 / 3}\right) \mathrm{O}_{3}-\mathrm{PbTiO}_{3}$ system. 
隔を 400〜 600 $\mu \mathrm{m}$ とすると, うまく分域の変化を観察 できた。なお，この電極には， $80^{\circ} \mathrm{C}$ 程度で付く銀電極 (EPO-TEC，H-20E) を用いた。

\section{3. 結 果}

\section{1 基礎特性}

亜鉛二オブ酸鉛とチタン酸鉛の固溶の割合を $(1-x)$ $\mathrm{Pb}\left(\mathrm{Zn}_{1 / 3} \mathrm{Nb}_{2 / 3}\right) \mathrm{O}_{3}-x \mathrm{PbTiO}_{3}$ として $x$ を用いて表すこ ととする.

ここで，この亜鉛二オブ酸鉛とチタン酸鉛の固溶系単 結晶の物性について簡単に説明する。まず亜鉛二オブ酸 鉛 $\mathrm{Pb}\left(\mathrm{Zn}_{1 / 3} \mathrm{Nb}_{2 / 3}\right) \mathrm{O}_{3}$ は，そのキュリ一温度が約 $140^{\circ} \mathrm{C}$ である複合ペロブスカイト構造の酸化物強誘電体であ り，室温における結晶構造は菱面体晶である。したがっ て，その分極方向はく $111>$ 軸であり，分極のなす角度 は約 71 度と 180 度である。次にチタン酸鉛 $\mathrm{PbTiO}_{3}$ は, キュリー温度が約 $490^{\circ} \mathrm{C}$ のペロブスカイト構造の酸化 物強誘電体であり, 室温での結晶構造は正方晶である. この場合, 分極方向は<100>であり，分極のなす角度 は 90 度と 180 度となる。

この二つを固溶することにより作製された単結晶は， $\mathrm{Pb}\left(\mathrm{Zn}_{1 / 3} \mathrm{Nb}_{2 / 3}\right) \mathrm{O}_{3}$ を $10 \mathrm{~mol} \%$ だけ $\mathrm{PbTiO}_{3}$ に置換した 組成物で, 室温において菱面体晶と正方晶の相境界（モ ルフォトロピック相境界) があり，この近傍の組成物は 優れた圧電性を示し，また電気機械結合係数も非常に大 きい"1).このほかにも，この固溶系の単結晶は，同じよ うに菱面体晶一正方晶相境界において大きな圧電性を示 す PZT 系単結晶に比べると，フラックス法を用いるこ とにより比較的大きな単結晶を容易に得ることができる という特長がある。

$\mathrm{Pb}\left(\mathrm{Zn}_{1 / 3} \mathrm{Nb}_{2 / 3}\right) \mathrm{O}_{3}$ の誘電率の温度に対する変化は散 漫な相転移を示すが2),3， $\mathrm{PbTiO}_{3}$ を加えるに従い， シャープな相転移を示すようになることが既に報告され

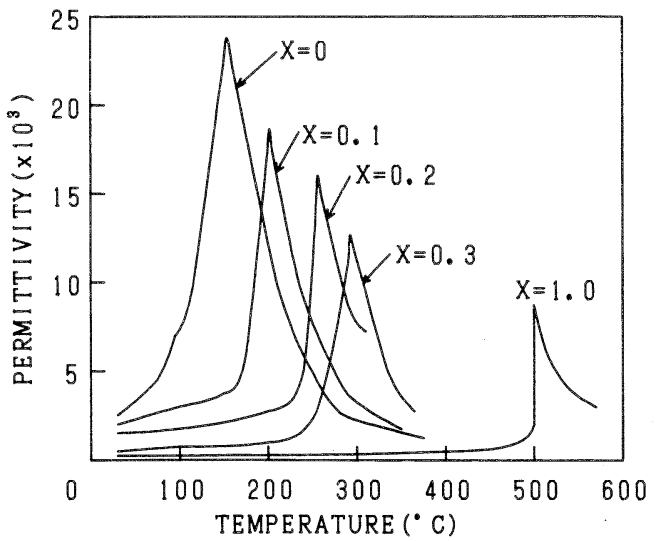

Fig. 4. Permittivity versus temperature curves for the $(1-x) \mathrm{Pb}\left(\mathrm{Zn}_{1 / 3} \mathrm{Nb}_{2 / 3}\right) \mathrm{O}_{3}-x \mathrm{PbTiO}_{3}$ system.
ている ${ }^{2) \sim 4)}$. 図 4 には誘電率の温度依存性の測定例を示 した．この固溶系の相図は図5に示したようになってい る.

\section{2 温度変化時の分域観察結果}

今回の観察では，室温付近において菱面体晶と正方晶 のモルフォトロピック相境界があるものを含んだ

(1) $x=0$,

(2) $x=0.07$,

(3) $x=0.095$,

という割合の 3 種類の試料を用いた。

ここでは，まず温度を室温から $200^{\circ} \mathrm{C}$ 程度までの範 囲で変化させたときの各単結晶の分域の変化の様子を示 す. 前で述べたように，すべての観察の結果はVTRに 収めてあり, 本論文ではその変化の様子を記述するとと もに, 特に変化の著しいところを中心に写真にして示し た。

(1) $x=0$ の場合

この単結晶の相転移温度は, 図 5 の相図からわかるよ うに約 $140^{\circ} \mathrm{C}$ であり, 菱面体晶から立方晶へと, 極め て散漫な相転移をする。 まず室温においては, 菱面体晶 であり，細長く数 $\mu \mathrm{m}$ 程度の紡錘形の分域構造が観察さ れた (図6 $(\mathrm{a})$ )。室温から温度を上げるに従い, 分域構 造は徐々に変化し始め, $95^{\circ} \mathrm{C}$ で暗くなりはじめ, $120^{\circ} \mathrm{C}$ では真っ暗になってしまった。図6(b) は，120ㄷ いて光量を上げて撮影したもので，分域はほよんど観察 できず画面が暗いことからも，ほぼ立方晶へ相転移して いると考えられる。

(2) $x=0.07$ の場合

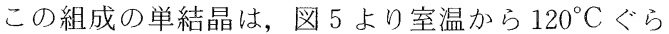

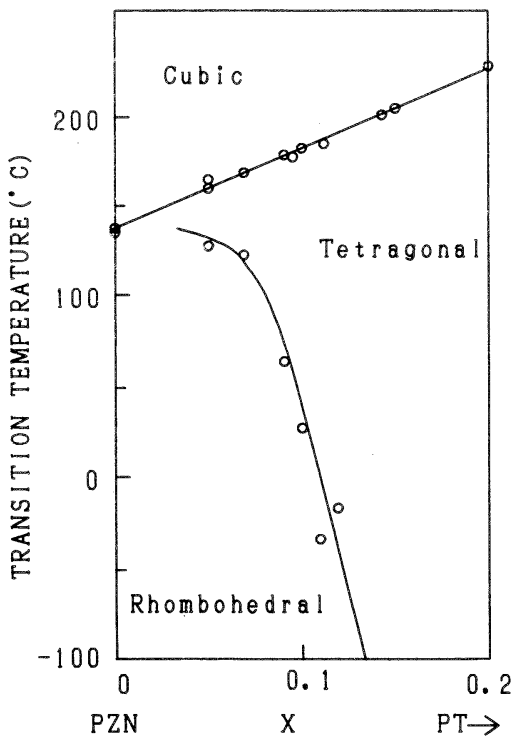

Fig. 5. Phase diagram of the $(1-x) \mathrm{Pb}\left(\mathrm{Zn}_{1 / 3} \mathrm{Nb}_{2 / 3}\right)$ $\mathrm{O}_{3}-x \mathrm{PbTiO}_{3}$ system. 

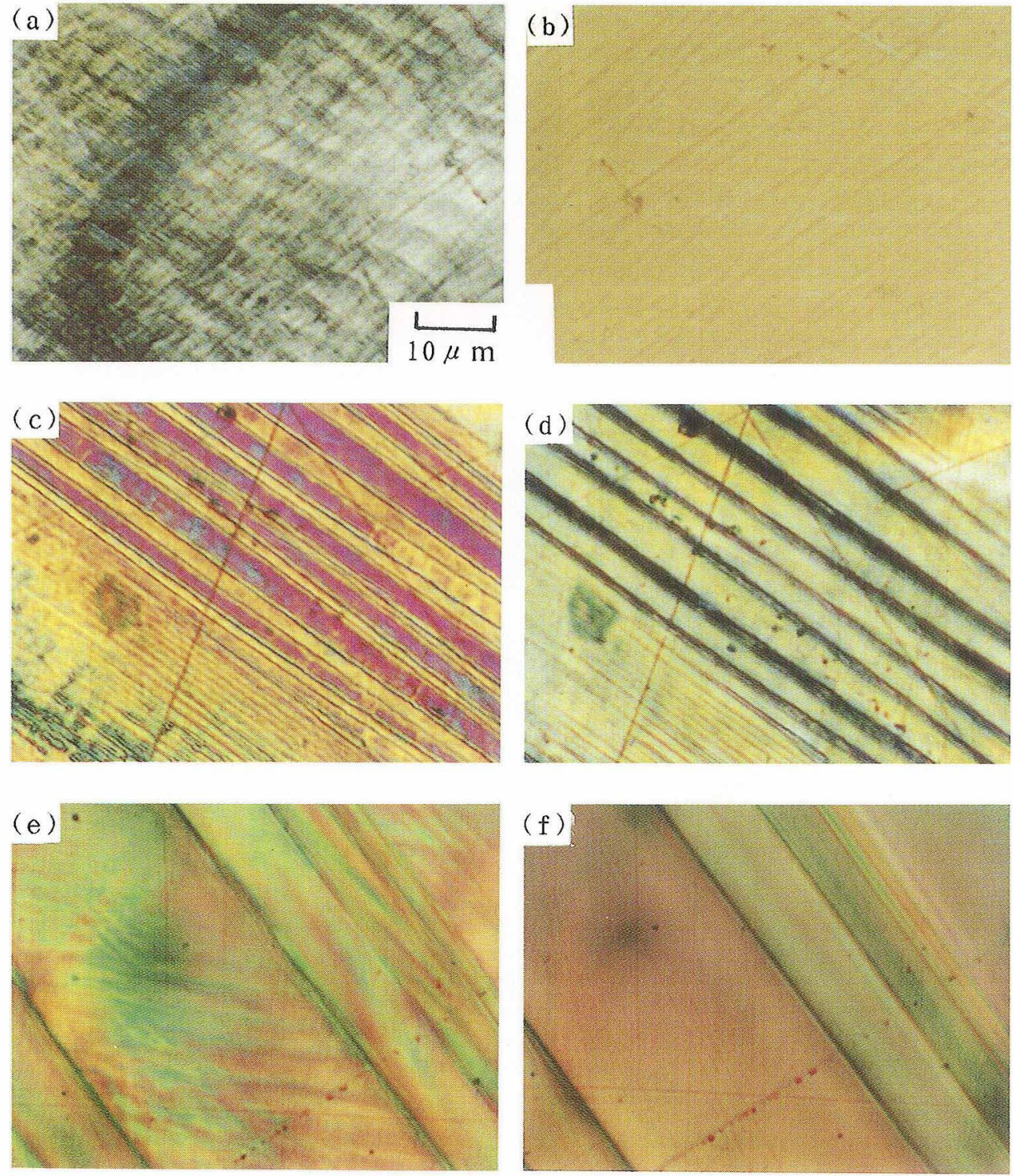

Fig. 6. (a) $x=0$ at $T=28^{\circ} \mathrm{C}$. Notice the small spindle-like domains. (b) $x=0$ at $T=120^{\circ} \mathrm{C}$. No domain is observed. (c) $x=0.07$ at $T=28^{\circ} \mathrm{C}$. (d) $x=0.07$ at $T=113^{\circ} \mathrm{C}$. (e) $x=0.095$ at $T=28^{\circ} \mathrm{C}$. Notice that the spindle-like domains exist between the sharp straight domain boundaries. (f) $x=0.095$ at $T=112^{\circ} \mathrm{C}$. The sharp domains remain after the spindle-like domains disappear.

いまでは菱面体晶， $170^{\circ} \mathrm{C} く$ らいまでは正方晶で，それ 以上では立方晶上変化する。室温においては菱面体晶で あるが，図6(c) に示すように図6(a) で観察されたも のよりも，かなり細長い (一数十 $\mu \mathrm{m})$ 紡錘形の分域が 見えた。室温から温度を上げ始めると, $90^{\circ} \mathrm{C}$ 付近で色 が変化し始めた。図6(d) は, $113^{\circ} \mathrm{C}$ における分域の様 子であるが，室温の様子（図6(c)）と比べると, 紡鍾 形をしていた黒い細い分域壁の先が開いて，平行になり つつあるように見える。これは，菱面体晶から正方晶に 変化し始めている様子と考えられる。更にこの後, 細い 線が多数入り始め, $118^{\circ} \mathrm{C}$ 付近でゆっくりと暗くなり始
めた。そして，ついに $172^{\circ} \mathrm{C}$ で画面は急に真っ暗になり， ここで立方晶へと相転移したことがわかった。

(3) $x=0.095$ の場合

この組成の単結晶は，図 5 から，室温付近において菱 面体晶と正方晶の相境界を持ち，更に $180^{\circ} \mathrm{C}$ 付近で立 方晶へ上変化する. 図6(e) は, 室温における菱面体晶 と正方晶の相境界の様子である。ややわかりづらいが, 直線状の分域壁の間に細かい紡錘形の分域がたくさんあ るように見える。これが，室温から温度を上げていくに 従い, $85^{\circ} \mathrm{C}$ 付近でその紡錘形の細かい分域が消え始め, 直線状の分域がはっきりしてくる。図6(f) は, $112^{\circ} \mathrm{C}$ 

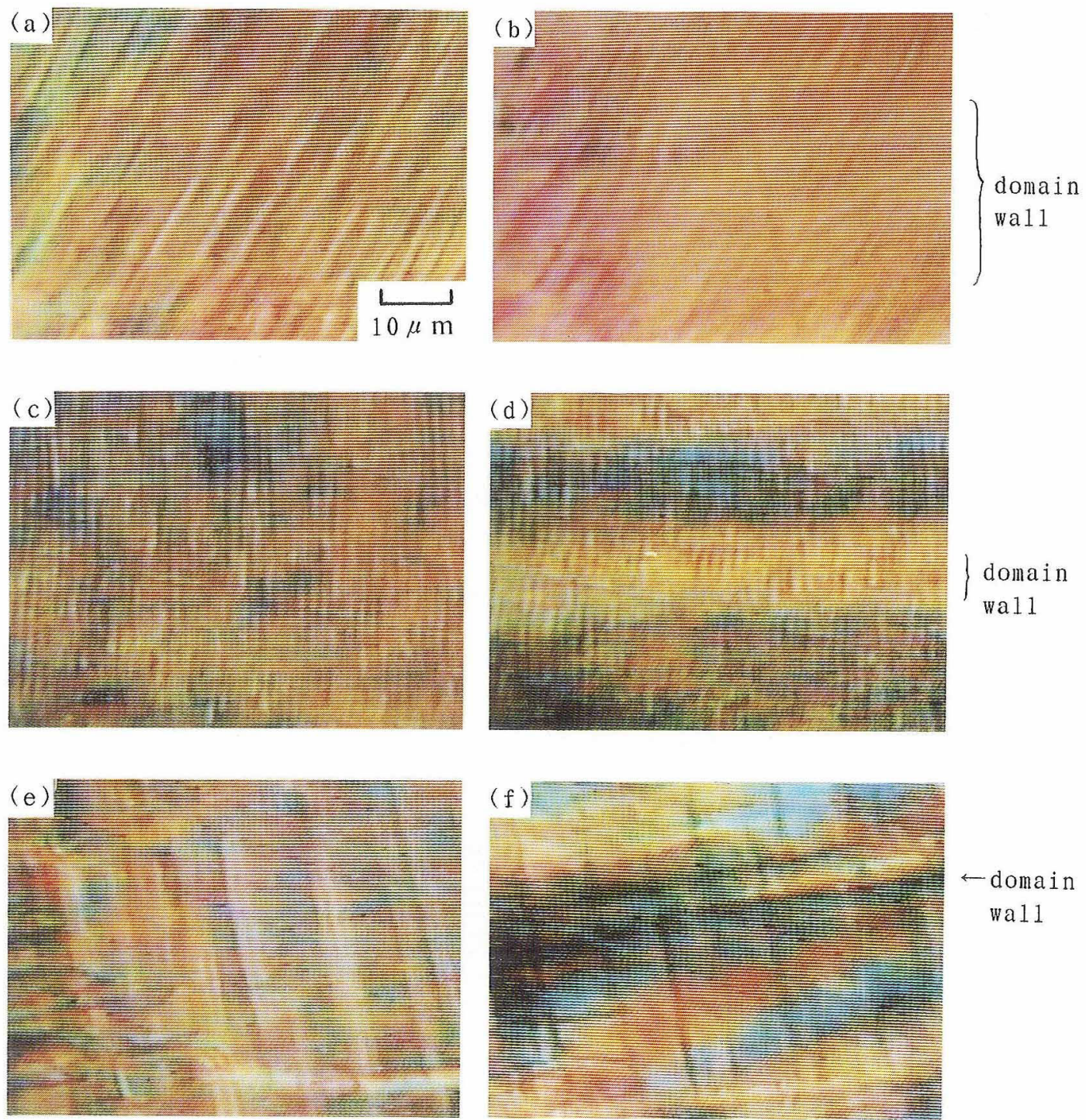

Fig. 7. (a) $x=0$ before domain reversal. (b) $x=0$ during domain reversal. (c) $x=0.07$ before domain reversal. (d) $x=0.07$ during domain reversal. (e) $x=0.095$ before domain reversal. (f) $x=0.095$ during domain reversal. Notice that the domain reversal front wall becomes sharp with an increase of $x$, leading to the phase transition sharpness.

における分域の様子で，紡錘形の細かい分域が完全に見 えなくなり，直線状の分域が見られる，ここで正方晶に なっていると考えられる，更に温度を上げていくと， $170^{\circ} \mathrm{C}$ ぐらいから赤っぽく色がつき始めた後, $180^{\circ} \mathrm{C} て$ くさび状に線が入り，直ちに画面は暗くなり，立方晶之 なった。つまり，菱面体晶相の分域は，正方晶相におけ る分域構造に強く影響されながら発生していると推察さ れる.

\section{3 電界印加時の観察結果}

ここでは, 各結晶に電界を印加したときの, 分域の変 化の様子を示す. 2.3 節で述べたように，研磨された結
晶表面に，直接電極を塗布し，電界をかけた。観察試料 には, $\pm 1000 \mathrm{~V}$ の正弦波を 50 秒の周期 $(0.02 \mathrm{~Hz})$ で 印加した。これらの観察結果も，すべてVTRに録画し てあり，本節でも前節にならってその変化の様子を記述 するとともに，特に変化の著しいところを中心に写真に して示した.
(1) $x=0 （$ 図 7(a), (b)),
(2) $x=0.07$ (図 $7(\mathrm{c}),(\mathrm{d})$ ),
(3) $x=0.095$ (図 $7(\mathrm{e}),(\mathrm{f})$ ),

の 3 種類の $\mathrm{Pb}\left(\mathrm{Zn}_{1 / 3} \mathrm{Nb}_{2 / 3}\right) \mathrm{O}_{3}-\mathrm{PbTiO}_{3}$ 固溶系単結晶に 電界をかけたときの分域の変化の様子を順に示した。い 
ずれの写真でも, 電界方向は写真の上下方向であり, 前 者には分域反転前の様子を, 後者には分域反転時の様子 を示した. ビの組成でも, 電圧を上げたときの分域反転 時には, 激しく分域が変化する様子が観察できた. (1) $x$ =0では, もやっとした非常にあいまいな分域壁が比較 的ゆっくり移動するのに対して, (2) $x=0.07$ では移動 する分域壁は $10 \mu \mathrm{m}$ 程度の幅ではっきりしてくる. (3) $x=0.095$ では, かなり明確な直線状の分域壁が形状を 維持したまま特定の電界 (抗電界) 以上になると, 速い 速度で移動するのが観察できた。また，どの試料につい ても分域反転後, 更に電界を上げていっても完全な単分 域状態を観察することはできなかった。

\section{4. 結 論}

著者らは, ランダムなイオン配列を持つ複合ペロブス カイト酸化物が，なぜ高い誘電率，また誘電緩和現象を 示すのかということについて研究を行っており，その一 環として, 今回このような酸化物結晶の動的な分域観察 を行い初好成功した。

ペロブスカイト型結晶構造を持つ強誘電体の多くは, キュリ一温度において, 強誘電相と常誘電相との間で相 転移をする. チ夕ン酸鉛においては, 非常に狭い温度領 域でシャープな相転移が起こる。これに対して, 重鉛二
オブ酸鉛のように複合ペロブスカイトでランダムなイオ ン配列をもつものでは，イオン分布の統計的な不均一さ なよ゙のために，キュリー温度が局所において異なり，そ のために相転移が広い温度領域にわたって散漫になる。 このことは温度変化による分域観察においても明瞭に示 された．亜鉛ニオブ酸鉛にチタン酸鉛を加えるに従い, その相転移はシャープになっていくが, 今回の実験結果 から, その分域構造も, 細かい紡錘形の分域から明瞭で 直線的な分域へと変化するということが実際に観察され た。

また，覀鉛二オブ酸鈶の低温における強誘電相の緩和 的な誘電分散, すなわち誘電率の周波数依存性は, 非常 にあいまいな比較的ゆっくりとした分域壁移動に由来す るのであろう。つまり, 強誘電体の相移転の散漫さや誘 電緩和性は, 分域の動的な挙動と密接な関係があるとい うことがわかった。

\section{文献}

1) J. Kuwata, K. Uchino and S. Nomura, Ferroelectrics, 22, $863(1979)$.

2) Y. Yokomizo, T. Takahashi and S. Nomura, J. Phys, Soc. Jpn., 28, 1278 (1970).

3) S. Nomura, H. Arima and F. Kojima, Jpn. J. Appl. Phys, 12, 531 (1973).

4) 野村昭一郎, 内野研二, 固体物理, 18, 71 (1982)。 